\title{
Peran tes kalori dan dynamic visual acuity pada pasien tuberkulosis yang mendapat terapi streptomisin
}

\author{
Widayat Alviandi, Brastho Bramantyo, Jenny Bashiruddin, Novra Widayanti \\ Departemen Ilmu Kesehatan Telinga Hidung Tenggorok-Bedah Kepala Leher \\ Fakultas Kedokteran Universitas Indonesia/ Rumah Sakit Dr. Cipto Mangunkusumo \\ Jakarta
}

\begin{abstract}
ABSTRAK
Latar belakang: Gangguan keseimbangan merupakan efek samping pemberian streptomisin yang dapat menurunkan kualitas hidup. Saat ini belum didapatkan penelitian gangguan keseimbangan pada pasien tuberkulosis yang mendapat terapi streptomisin, yang diperiksa menggunakan tes dynamic visual acuity (DVA) dan tes kalori. Tujuan: Penelitian ini bertujuan untuk melihat akurasi pemeriksaan keseimbangan dengan DVA pada pasien TB yang mendapatkan streptomisin dibandingkan dengan elektronistagmografi (ENG). Metode: Penelitian ini merupakan penelitian pra-eksperimental untuk mengetahui perubahan hasil pemeriksaan fungsi keseimbangan vestibuler pada suatu kelompok pasien TB sebelum dan setelah 56 kali pemberian streptomisin, atau bila timbul keluhan gangguan keseimbangan dengan tes DVA dan tes kalori, selama April-Oktober 2014. Digunakan rancangan uji diagnostik untuk membandingkan kedua cara pengukuran setelah pengobatan. Hasil: Setelah pemberian terapi dilakukan pemeriksaan kalori pada $31(77,5 \%)$ dari 40 subjek dan $30(75 \%)$ dengan pemeriksaan DVA. Rerata nilai kalori sebelum terapi sebesar $93,5 \pm 32,07 \%$ detik dan setelah terapi sebesar $82,30 \pm 38,43 \%$ detik, terjadi perubahan sebesar $-11,25 \pm 50,55^{\circ}$ /detik. Median nilai kenaikan DVA sebelum terapi adalah 0 (minimal 0-maksimal 2) baris dan setelah terapi adalah 3 (minimal 0-maksimal 6) baris, terjadi perubahan sebesar 3 (minimal 0-maksimal 5) baris. Sensitivitas pemeriksaan DVA $83 \%$, spesifisitas $27 \%$, nilai duga positif $17 \%$, nilai duga negatif $90 \%$, rasio kemungkinan positif 1,13 , dan rasio kemungkinan negatif 0,63 dengan pemeriksaan kalori sebagai baku emas. Kesimpulan: Pemeriksaan DVA dapat digunakan sebagai skrining pemeriksaan kelemahan vestibuler perifer bilateral pada pasien tuberkulosis yang mendapat terapi streptomisin.
\end{abstract}

Kata kunci: dynamic visual acuity, tes kalori, elektronistagmografi, kelemahan vestibuler perifer bilateral

\section{ABSTRACT}

Background: Impaired balance is the side effect of Streptomycin administration which can decrease the quality of life Up till now, there is no research yet on dynamic visual acuity (DVA) and caloric test in tuberculosis (TB) patients receiving streptomycin therapy. Objective: This study aims to look at the accuracy of the examination using DVA in TB patients receiving Streptomycin, compared to using electronistagmography (ENG). Methods: A pre-experimental study was used to determine changes in the vestibular function test results in a group of TB patients before and after56times administration of Streptomycin, or when subjects complained of balance disorders, with DVA test and caloric test during April-October 2014. Designed diagnostic test was used after treatment to compare the two methods of measurement. Result: After therapy there was 31 (77.5\%) out of 40 subjects with caloric examination in 30 (75\%) subjects with DVA examination. The mean value of caloric examination before therapy was $93.5 \pm 32.07 \% \mathrm{sec}$ and after therapy was $82.30 \pm 38.43 \% \mathrm{sec}$, the change was- $11.25 \pm 50.55^{\circ} / \mathrm{sec}$. The median value of increased DVA line before therapy was 0 line and after therapy was 3 line, there was a change of 3 (minimum 0-maximum 5) line. DVA examination has a sensitivity of $83 \%$, a specificity of $27 \%$, positive predictive value $17 \%$, negative predictive value $90 \%$, a positive likelihood ratio 1.13 and a negative likelihood ratio 0.63 with caloric examination as the gold standard. Conclusion: DVA examination can be used as a screening tool in bilateral peripheral vestibular weakness in TB patients who received Streptomycin therapy. 
Keywords: bilateral peripheral vestibular weakness, dynamic visual acuity, calorictest,

electronystagmography

Alamat korespondensi: Dr. Widayat Alviandi, Sp.T.H.T.K.L (K). Departemen Ilmu Kesehatan Telinga Hidung Tenggorok-Bedah Kepala Leher, Fakultas Kedokteran Universitas Indonesia. Rumah Sakit Dr. Cipto Mangunkusumo, Jakarta. Jl. Diponegoro No.71, Salemba Jakarta Pusat. Email: widayat_alviandi@, yahoo.com

\section{PENDAHULUAN}

Tuberkulosis (TB) adalah penyakit menular langsung yang disebabkan oleh kuman TB yaitu Mycobacterium tuberculosis. Data WHO (World Health Organization) tahun 2012 menyebutkan jumlah kasus baru TB di seluruh dunia pada tahun 2012 tercatat sebanyak 8,6 juta, dimana $58 \%$ berada di regio Asia Tenggara. Data dari subdirektorat TB Direktorat Jendral Pengendalian Penyakit dan Penyehatan Lingkungan Kementrian Kesehatan Republik Indonesia (Kemenkes RI) menunjukkan jumlah penderita TB di Indonesia tahun 2012 sekitar 460.000 dan penderita TB paru pengobatan ulang (kategori II) sebanyak 7380. Kepustakaan menyebutkan bahwa $75 \%$ penderita TB adalah usia produktif yang berkisar antara 15-50 tahun. ${ }^{1-4}$

Streptomisin merupakan salah satu jenis antibiotik yang digunakan untuk pengobatan TB kategori II. Obat ini bersifat ototoksik dan dapat menimbulkan gejala tinitus, pendengaran berkurang, serta gangguan keseimbangan..$^{5,6}$ Diagnosis gangguan keseimbangan akibat ototoksisitas streptomisin memerlukan pemeriksaan penunjang antara lain tes Dynamic Visual Acuity (DVA) dan elektronistagmografi (ENG). ${ }^{7}$ Pemeriksaan dengan ENG memerlukan biaya yang mahal dan pemeriksa yang terlatih, sehingga tidak semua fasilitas kesehatan memiliki alat ini, sedangkan pemeriksaan DVA dilakukan dengan menggunakan Snellen chart yang dipasang sejauh 2 meter dari bangku pemeriksaan dengan ketinggian sekitar titik pandang lurus pasien, kepala pasien ditundukkan $30^{\circ}$ dan digerakkan sesuai bidang horizontal dengan kecepatan 2 $\mathrm{Hz}$ mulai dari sisi kanan/kiri sejauh $20^{\circ}-30^{\circ}$ dari garis tengah. Saat kepala digerakkan pasien diminta membaca huruf pada Snellen chart. Penurunan tajam penglihatan atau kenaikan baris yang dapat dibaca sebesar satu baris dianggap normal, sedangkan kenaikan lebih dari dua baris menunjukkan adanya gangguan vestibulo ocular reflex (VOR). Tes DVA menggunakan komputer merupakan pemeriksaan DVA secara aktif. Huruf akan ditampilkan dilayar bila pergerakan kepala di atas ambang kecepatan 120-150\% detik. ${ }^{8-11}$

Pemeriksaan DVA dapat menjadi salah satu cara evaluasi gangguan keseimbangan pada pasien TB yang mendapat terapi streptomisin serta dapat dilakukan pada fasilitas kesehatan primer termasuk pusat kesehatan masyarakat (Puskesmas). Saat ini belum ada penelitian dampak gangguan keseimbangan pada pasien TB yang diterapi dengan streptomisin dan diperiksa menggunakan tes DVA dibandingkan dengan tes kalori pada pemeriksaan ENG sebagai baku emas.

Tujuan penelitian ini adalah untuk melihat akurasi pemeriksaan keseimbangan dengan DVA pada pasien TB yang mendapatkan Streptomisin dibandingkan dengan ENG.

\section{METODE}

Penelitian ini merupakan penelitian dengan desain pra-eksperimental (desain penelitian eksperimen satu kelompok dengan pengamatan sebelum dan setelah 
perlakuan atau pemberian obat) untuk mengetahui perubahan hasil pemeriksaan fungsi keseimbangan vestibuler pada satu kelompok pasien TB sebelum dan setelah 56 kali pemberian streptomisin, atau bila timbul keluhan gangguan keseimbangan dengan tes DVA dan tes kalori. Digunakan rancangan uji diagnostik untuk melihat akurasi pemeriksaan keseimbangan dengan DVA pada pasien TB yang mendapatkan Streptomisin dibandingkan dengan ENG .

Penelitian ini dilakukan di Divisi Neurotologi Departemen Telinga Hidung Tenggorok-Bedah Kepala Leher (THTKL) Fakultas Kedokteran Universitas Indonesia (FKUI)/ Rumah Sakit Dr. Cipto Mangunkusumo (RSCM), Divisi Pulmonologi Departemen Ilmu Penyakit Dalam FKUIRSCM, Departemen Pulmonologi, dan Ilmu Kedokteran Respirasi FKUI/ Rumah Sakit Umum Pemerintah (RSUP) Persahabatan. Pelaksanaan penelitian dilakukan pada AprilOktober 2014.

Subjek penelitian adalah semua orang pada populasi terjangkau yang sesuai dengan kriteria penerimaan dan penolakan subjek penelitian. Kriteria penerimaan meliputi 1)
Pasien yang datang ke poliklinik Paru dan unit pelaksana teknis human immunodeficiency virus (UPT HIV) RSCM serta poliklinik Paru RSUP Persahabatan, dan didiagnosis sebagai pasien TB berdasarkan anamnesis, pemeriksaan fisik serta pemeriksaan penunjang, dan akan mendapat terapi streptomisin, 2) Laki-laki dan perempuan, usia 18 tahun hingga 60 tahun, 3) Bersedia mengikuti prosedur penelitian dengan menandatangani surat persetujuan (informed consent). Adapun kriteria penolakan adalah 1) Pasien dengan riwayat penggunaan streptomisin atau obat ototoksik lain sebelumnya, 2) Pasien dengan perforasi membran timpani dan gangguan telinga tengah (timpanogram selain tipe A), 3) Pasien dengan riwayat gangguan keseimbangan sebelumnya berdasarkan anamnesis, 4) Pasien tidak dapat membaca huruf pada 3 baris teratas di Snellen chart dalam jarak dua meter, terdapat gangguan pergerakan mata, atau strabismus, 5) Pasien dengan gangguan servikal leher serta punggung.

Besar subjek penelitian adalah 57 dan diambil secara berurutan (consecutive sampling) selama 6 (enam) bulan, atau sampai jumlah subjek terpenuhi. Subjek

Tabel 1. Karakteristik subjek penelitian setelah terapi $(n=40)$

\begin{tabular}{|c|c|c|c|c|c|c|c|}
\hline Variabel & & Pem & saan kalori & $\mathbf{p}$ & Peme & an DVA & $\mathbf{p}$ \\
\hline kelemahan vestibı & Iler & + & - & & + & - & \\
\hline Jenis kelamin & n $(\%)$ & & & & & & \\
\hline Laki-laki & $23(57,5)$ & 4 & 19 & $1,000^{*}$ & 20 & 3 & $0,066^{*}$ \\
\hline Perempuan & $17(42,5)$ & 2 & 15 & & 10 & 7 & \\
\hline Pendidikan & n $(\%)$ & & & & & & \\
\hline Rendah-menengah & $28 \quad(70)$ & 5 & 23 & 0,648 & 20 & 8 & \\
\hline Tinggi & $12 \quad(30)$ & 1 & 11 & & 10 & 2 & \\
\hline Dosis & n (\%) & & & & & & \\
\hline Ringan-sedang & $7(17,5)$ & 0 & 7 & $0,567^{*}$ & 5 & 2 & $1,000^{*}$ \\
\hline Tinggi & $33(82,5)$ & 6 & 27 & & 25 & 8 & \\
\hline Lama terapi & hari & & & & & & \\
\hline Singkat-sedang & 7 & 1 & 6 & $1,000^{*}$ & 6 & 1 & $0,656^{*}$ \\
\hline Lama & 33 & 1 & 6 & & 24 & 9 & \\
\hline Total obat hingga & keluhan timbul & n $(\%$ & & & & & \\
\hline Ringan-sedang & $17(42,5)$ & 2 & 15 & $1,000 *$ & 17 & 0 & $0,165^{*}$ \\
\hline Tinggi & $23(57,5)$ & 4 & 19 & & 14 & 9 & \\
\hline
\end{tabular}

$\mathrm{p}^{*}$ Uji Fisher 
Tabel 2. Gangguan keseimbangan setelah terapi berdasarkan pemeriksaan kalori, DVA, dan anamnesis

\begin{tabular}{|c|c|c|c|c|c|c|c|}
\hline & & Pemel & kal & $\mathbf{p}^{*}$ & Pemer & DVA & $\mathbf{p}^{*}$ \\
\hline Kelemaha & & + & - & & + & - & \\
\hline Keluhan & + & 5 & 26 & 0,001 & 28 & 3 & 1,000 \\
\hline & - & 1 & 8 & & 2 & 7 & \\
\hline Total & & 6 & 34 & & 30 & 10 & \\
\hline
\end{tabular}

* Uji McNemar

Tabel 3. Perubahan hasil pemeriksaan kalori dan pemeriksaan DVA setelah terapi streptomisin

\begin{tabular}{|c|c|c|}
\hline & Pemeriksaan kalori ( $\%$ det) & Pemeriksaan DVA (baris) \\
\hline Sebelum & $93,55 \pm 32,07^{\circ}$ & $0(0-2)^{\mathrm{ax}}$ \\
\hline Setelah & $82,30 \pm 38,43^{a}$ & $3(0-6)$ \\
\hline Perubahan & $-11,25 \pm 50,55^{\circ}$ & $3(0-5)$ \\
\hline $\mathbf{p}$ & $0,167^{*}$ & $0,001^{* *}$ \\
\hline IK95\% & $-27,41-4,91$ & $2,82-3,06$ \\
\hline \multicolumn{3}{|c|}{ 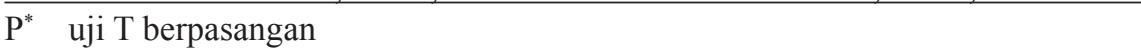 } \\
\hline \multicolumn{3}{|c|}{$\mathrm{P}^{* *} \quad$ uji Wilcoxon } \\
\hline \multicolumn{3}{|c|}{ Rerata \pm SD } \\
\hline \multicolumn{3}{|c|}{ Median (mimimum - maksimal) } \\
\hline
\end{tabular}

yang memenuhi kriteria penelitian dan tidak terdapat kondisi sesuai dengan kriteria penolakan diikutsertakan dalam penelitian.

Semua data yang telah terkumpul diedit dan dikoding, kemudian dimasukkan dalam lembar kerja, diproses dalam komputer dengan menggunakan perangkat lunak SPSS 20 (Statistical Package for Social Science). Data diolah secara statistik deskriptif dan disajikan dalam bentuk teks, tabel, atau grafik. Analisis univariat dilakukan untuk menyajikan data karakteristik subjek untuk melihat nilai tengah dan deviasinya, atau sebaran frekuensinya. Sementara analisis bivariat untuk data kategorik berpasangan menggunakan uji McNemar dengan nilai kemaknaan adanya perbedaan proporsi antara kedua cara pemeriksaan bila nilai $\mathrm{p}<0,05$. Selanjutnya berdasarkan tabel $2 \times 2$ dilakukan penghitungan untuk menilai sensitivitas, spesifisitas, nilai prediksi positif, nilai prediksi negatif dan rasio kemungkinan.

\section{HASIL}

Penelitian ini telah dilakukan pada April-Oktober 2014 di Poliklinik Neurotologi Departemen THT-KL FKUI-RSCM dan didapatkan 42 subjek penelitian yang sesuai dengan kriteria penelitian yang telah ditetapkan namun hanya 40 orang yang menyelesaikan pengobatan hingga masa penilaian selesai, 2 subjek putus obat dan tidak kontrol kembali.

Rerata usia subjek penelitian adalah $38,13 \pm 11,25$ tahun. Terdapat 5 subjek dengan HIV, 1 subjek memiliki hipertensi, 2 subjek memiliki diabetes melitus, dan 2 subjek dengan SLE. Dilakukan pemeriksaan audiometri sebelum dan setelah terapi. Nilai rata-rata ambang dengar disajikan dalam bentuk nilai median (minimal-maksimal). Sebelum terapi ambang dengar rata-rata telinga kanan adalah $16,25(6,25-63,50)$ $\mathrm{dB}$ dan telinga kiri 18,38 (7,50-88,75) $\mathrm{dB}$. Setelah terapi didapatkan ambang dengar ratarata telinga kanan adalah $16,25(8,75-71) \mathrm{dB}$ dan kiri sebesar 17,5 $(11,25-82,5) \mathrm{dB}$. 
Tabel 4. Hasil pemeriksaan DVA dan pemeriksaan kalori setelah terapi streptomisin

\begin{tabular}{cccccc}
\hline \multirow{2}{*}{ Pemeriksaan DVA } & \multicolumn{2}{c}{ Pemeriksaan kalori } & \multirow{2}{*}{ Total } & \multirow{2}{*}{$\mathbf{p}^{*}$} \\
\cline { 2 - 4 } & + & - & & \\
\hline+ & 5 & 25 & & 30 & 0,001 \\
- & 1 & 9 & & 10 & \\
\hline Total & 6 & 34 & 40 & \\
\hline
\end{tabular}

*Uji McNemar

Data karakteristik subjek penelitian yang diamati pada penelitian ini disajikan pada tabel 1. Dalam analisis statistik dilakukan penggabungan data. Data pendidikan dikelompokkan menjadi pendidikan rendahmenengah (Sekolah Dasar-Sekolah Menengah Atas) dan tinggi (Diploma 3-Strata2). Dosis streptomisin yang digunakan dikelompokkan menjadi ringan-sedang (500mg-750mg) dan tinggi (1gram), lama pemakaian dikelompokkan menjadi singkat-sedang (045 hari) dan lama (46-60), sedangkan dosis total dikelompokkan menjadi ringan-sedang (0-40 gram) dan tinggi (41-60 gram).

Tabel 2. menunjukkan 31 (77,5\%) subjek mengeluhkan gangguan keseimbangan setelah terapi streptomisin berdasarkan anamnesis. Keluhan yang sering timbul adalah rasa goyang dan melayang. Tidak didapatkan keluhan pusing berputar. Dari 10 subjek dengan penyakit penyerta seperti HIV, hipertensi, diabetes melitus, dan SLE ternyata 1 orang dengan HIV tidak mengeluhkan adanya gangguan keseimbangan. Hasil pemeriksaan kalori dan DVA dikatakan positif bila terdapat kelemahan fungsi vestibuler perifer bilateral.

Menggunakan uji T berpasangan, maka tidak didapatkan perbedaan rerata yang bermakna $(p>0,05)$ berarti pemberian terapi streptomisin tidak berpengaruh terhadap rerata nilai kalori. Menggunakan uji Wilcoxon didapatkan perubahan nilai median kenaikan baris dari pemeriksaan DVA yang bermakna $(p<0,05)$. Berarti pemberian terapi streptomisin menyebabkan kenaikan dari baris huruf yang dapat dibaca pada pemeriksaan DVA (Tabel 3).
Tabel 4 memperlihatkan hasil pemeriksaan DVA dibandingkan pemeriksaan kalori. Sebanyak 30 subjek dengan hasil pemeriksaan DVA positif (kelemahan fungsi vestibuler perifer bilateral), namun hanya 5 subjek dengan hasil pemeriksaan kalori positif. Pada 10 subjek dengan pemeriksaan DVA negatif ternyata 9 subjek didapatkan hasil negatif pada pemeriksaan kalori. Dari uji McNemar terdapat perbedaan bermakna antara pemeriksaan DVA dengan pemeriksaan kalori $(\mathrm{p}<0,05)$. Dari uji diagnostik pemeriksaan DVA dengan kalori sebagai baku emas didapatkan nilai sensitivitas $83 \%$, spesifisitas $27 \%$, nilai duga positif $17 \%$, nilai duga negatif $90 \%$, rasio kemungkinan positif 1,13 , dan rasio kemungkinan negatif 0,63 . Umumnya rasio kemungkinan positif di atas 10 dan rasio kemungkinan negatif dibawah 0,1 dianggap mempunyai nilai diagnostik yang baik. Nilai rasio kemungkinan sekitar 1 menunjukan hasil uji dengan kekuatan sedang.

\section{DISKUSI}

Penelitian ini melibatkan 40 subjek penelitian yang terdiri dari 23 orang lakilaki dan 17 orang perempuan. Hal ini sesuai dengan hasil Riskesdas tahun 2013 yaitu jumlah prevalensi penderita TB lakilaki lebih banyak dari perempuan. Subjek terbanyak pada penelitian ini dengan tingkat pendidikan SMA dan usia rerata $38,13 \pm 11,25$, sedangkan menurut Riset Kesehatan Dasar (Riskesdas) 2013 prevalensi TB paru cenderung meningkat dengan bertambahnya umur dan pada pendidikan rendah. ${ }^{12}$ Dengan bertambahnya umur maka daya tahan seseorang terhadap adanya 
infeksi makin berkurang, sehingga risiko terkena tuberkulosis juga makin meningkat. Tingkat pendidikan yang rendah berhubungan dengan sosio-ekonomi, sehingga pada orang dengan pendidikan rendah kemungkinan sosio-ekonomi kurang, gizi kurang, dan pengetahuan tentang kesehatan juga kurang, yang dapat berakibat kurang patuhnya pengobatan TB.

Pada penelitian ini didapatkan dosis streptomisin yang paling banyak diberikan adalah 1 gram (33 subjek). Dari Pedoman Nasional Penanganan Tuberkulosis serta Pedoman Diagnosis dan Penatalaksanaan Tuberkulosis di Indonesia maka dosis streptomisin untuk berat badan $>55 \mathrm{~kg}$ diberikan dosis 1 gram. Pada subjek penelitian sebagian besar merupakan dewasa muda, maka berat badan subjek rata-rata $>55 \mathrm{~kg}$. ${ }^{3,13}$

Jumlah obat kumulatif saat timbul keluhan gangguan keseimbangan banyak ditemukan setelah 41 gram. Ototoksisitas streptomisin berhubungan dengan jumlah kumulasi obat dalam tubuh. Hasil ini sesuai dengan penelitian Kim dkk. ${ }^{14}$ yang mendapatkan bahwa toksisitas vestibuler terhadap streptomisin terjadi setelah $41,5 \pm 18,7$ hari, sedangkan koklea pada 59,6 $\pm 22,0$ hari. Keluhan gangguan pendengaran terjadi lebih lambat dari gangguan keseimbangan, oleh karena itu penurunan pendengaran tidak dapat dijadikan indikator awal ototoksisitas akibat streptomisin. Ranger ${ }^{15}$ pada penelitiannya mendapatkan bahwa ototoksisitas dapat terjadi setelah pemberian total 5 gram, 20 gram, 50 gram, dan 100 gram. Banyak faktor yang memengaruhi toksisitas streptomisin terhadap seseorang, sehingga sulit memperkirakan pada siapa dan dosis berapa ototoksik akan terjadi. Namun makin besar dosis obat per hari makin tinggi risiko toksisitas.

Pada penelitian ini tidak didapatkan hubungan yang bermakna antara jenis kelamin, pendidikan, dosis streptomisin, dan lama pemakaian dengan hasil pemeriksaan kalori dan DVA setelah terapi. Timoteo ${ }^{16}$ mengemukakan bahwa tidak terdapat hubungan yang bermakna antara penurunan ambang dengar dan keluhan gangguan keseimbangan dibandingkan dengan jenis kelamin, usia, jumlah streptomisin, lama penggunaan streptomisin, riwayat penggunaan sebelumnya, dan riwayat TB di keluarga yang diperiksa menggunakan audiometri, emisi otoakustik serta anamnesis keluhan gangguan keseimbangan.

Pada penelitian ini setelah diberikan terapi streptomisin diperoleh 31 dari 40 (77,5\%) subjek mengeluhkan gangguan keseimbangan yaitu rasa goyang, melayang, tidak stabil, dan ingin jatuh bila berjalan. Rizzi dkk. ${ }^{17}$ menyatakan bahwa pasien yang mengalami vestibulotoksik setelah pemberian aminoglikosida mengeluhkan rasa goyang dan tidak stabil, jarang sekali yang mengeluhkan vertigo. Singh dkk. ${ }^{18}$ pada penelitiannya mendapatkan 40 dari $143(27,97 \%)$ kasus TB yang mendapat terapi streptomisin mengeluhkan adanya gangguan keseimbangan, sedangkan Kim dkk. ${ }^{19}$ mendapatkan 17 dari $418(4,2 \%)$ pasien TB yang mendapat terapi streptomisin mengeluhkan gangguan keseimbangan dan 5 subjek $(1,2 \%)$ mengeluhkan penurunan pendengaran. Hasil literature review oleh Selimoglu ${ }^{8}$ mendapatkan bahwa streptomisin lebih bersifat vestibulotoksik dibandingkan kokleotoksik. Hal ini berbeda dari penelitian Timoteo ${ }^{16}$ yang mendapatkan bahwa pada pasien yang diberikan streptomisin selama paling sedikit 15 hari, 75,1\% mengeluhkan penurunan pendengaran dan $61,1 \%$ menunjukkan gejala gangguan vestibuler.

Tiga puluh satu subjek penelitian ini mengeluhkan gangguan keseimbangan, namun hanya didapatkan 5 subjek (16\%) dengan kelemahan fungsi vestibuler perifer bilateral berdasarkan pemeriksaan kalori, dan 28 subjek (90\%) berdasarkan pemeriksaan DVA. Subjek tanpa keluhan gangguan keseimbangan sebanyak 9 subjek, namun ternyata terdapat 1 subjek dengan kelemahan 
fungsi vestibuler perifer bilateral berdasarkan pemeriksaan kalori, dan 2 subjek berdasarkan pemeriksaan DVA.

Hasil pemeriksaan kalori positif yang sedikit ini sesuai dengan penelitian Singh dkk. ${ }^{18}$ yaitu dari 40 subjek pasien TB yang mendapat terapi streptomisin dan mengeluh gangguan keseimbangan hanya 11 pasien (27,5\%) yang mengalami kelemahan fungsi vestibuler perifer bilateral berdasarkan pemeriksaan kalori. Viljoen dan Sellars ${ }^{20}$ mengemukakan dari penelitiannya pada 6 subjek yang mendapat terapi streptomisin hanya 1 subjek memiliki respon kalorik abnormal walaupun organ vestibuler lebih dulu terkena dibandingkan koklea.

Pada penelitian ini hasil pemeriksaan DVA positif sebesar $90 \%$, sesuai dengan penelitian yang dilakukan Kim dkk. ${ }^{19}$ Kim mendapatkan dari 17 subjek dengan gangguan keseimbangan setelah terapi streptomisin terdapat 12 subjek (70\%) mengalami penurunan VOR yang diperiksa menggunakan tes slow harmonic acceleration dan tes head thrust positif. Tidak ditemukan literatur mengenai efek streptomisin yang diperiksa menggunakan DVA, namun Ahmed dkk. ${ }^{21}$ pada penelitiannya mendapatkan dari 103 pasien dengan terapi gentamisin semua mengalami kelemahan fungsi vestibuler perifer bilateral berdasarkan pemeriksaan computerized DVA.

Data hasil penelitian ini mendapatkan perbedaan yang bermakna antara keluhan dan pemeriksaan kalori serta tidak terdapat perbedaan bermakna antara keluhan dan pemeriksaan DVA. Hasil penelitian ini sesuai dengan kepustakaan bahwa kecepatan pergerakan kepala pada gerakan seharihari berkisar antara 1-5 Hz dan kanalis semisirkularis berespon lebih efisien terhadap pergerakan angular 1-6 Hz. ${ }^{19,22}$ Pada pemeriksaan kalori, stimulus merangsang endolimf kanal lateral sesuai dengan pergerakan angular sebesar 0,002 sampai $0,004 \mathrm{~Hz}$, sehingga dapat disimpulkan bahwa tes kalori mengevaluasi kanalis semisirkularis dalam frekuensi non fisiologis. Pada pemeriksaan DVA, kepala digerakkan secara pasif dengan kecepatan $2 \mathrm{~Hz}$, sehingga pemeriksaan DVA sesuai dengan pergerakan fisiologis kepala dan mampu merangsang kanalis semisirkularis secara efisien., ${ }^{73-27}$

Hasil penelitian ini mendapatkan pada pemeriksaan kalori sebelum dan setelah pemberian terapi tidak terdapat perbedaan rerata yang bermakna. Zingler dkk. ${ }^{27}$ mendapatkan pada subjek dengan kelemahan fungsi vestibuler perifer bilateral karena aminoglikosida saat evaluasi lanjut terdapat penurunan nilai kalori yang tidak signifikan sebesar $1,5 \pm 1,1^{\circ} / \mathrm{det}$. Vital dkk. ${ }^{28}$ mendapatkan bahwa pada subjek dengan kelemahan fungsi vestibuler perifer bilateral didapatkan perubahan DVA rata-rata sebesar 1,40 $\pm 0,29 \log$ MAR diperiksa menggunakan computerized DVA. Kim dkk. ${ }^{19}$ mendapatkan penurunan VOR pada subjek setelah terapi streptomisin diperiksa menggunakan pemeriksaan slow harmonic acceleration.

Pada penelitian ini dilakukan uji diagnostik antara pemeriksaan DVA dan kalori sebagai baku emas. Menggunakan uji McNemar didapatkan perbedaan yang bermakna $(\mathrm{p}<0,001)$ antara pemeriksaan DVA dan kalori. Pada uji diagnostik didapatkan sensitivitas yang baik (83\%), namun spesifisitas kurang (27\%). Dengan sensitivitas yang baik maka pemeriksaan DVA dapat digunakan sebagai skrining terhadap gangguan keseimbangan pada pasien TB yang mendapat terapi streptomisin terutama pada layanan kesehatan yang tidak memiliki fasilitas yang lengkap, namun bila fasilitas memungkinkan sebaiknya pemeriksaan ini dilanjutkan dengan pemeriksaan kalori. Dengan menggunakan jumlah subjek sebanyak 40 dan sensitivitas $83 \%$ didapatkan power penelitian ini sebesar $89 \%$, ternyata dengan jumlah subjek yang kurang power penelitian ini masih baik, sehingga hasil penelitian ini dapat diaplikasikan. 
Penelitian ini menggunakan pemeriksaan DVA secara pasif, namun tidak ditemukan kepustakaan yang melakukan penelitian menggunakan DVA secara pasif pada subjek yang mendapat terapi streptomisin. Herdman dkk. ${ }^{29}$ seperti dikutip oleh Petersen mendapatkan pemeriksaan computerized DVA memiliki sensitivitas (94,5\%) dan spesifisitas $(95,2 \%)$ yang baik pada pasien dengan kelemahan fungsi vestibuler unilateral dan bilateral. Hal ini berbeda dengan penelitian oleh Schubert dkk. ${ }^{30}$ yang juga melakukan pemeriksaan DVAmenggunakan computerized DVA pada subjek yang sudah didiagnosis normal, hipofungsi vestibuler unilateral serta bilateral berdasarkan pemeriksaan kalori. Penelitian Schubert ${ }^{30}$ memberikan hasil pemeriksaan DVA spesifisik (90\% untuk hipofungsi vestibuler unilateral dan bilateral) namun tidak terlalu sensitif (23\% untuk hipofungsi vestibuler unilateral dan $55 \%$ untuk bilateral) untuk mendeteksi hipofungsi vestibuler perifer. Sensitivitas yang lemah pada penelitian Schubert mungkin disebabkan pada pemeriksaan dengan computerized DVA kepala subjek bergerak secara aktif, sehingga pasien dapat menggunakan mekanisme lain selain VOR untuk mengantisipasi fiksasi mata selama pemeriksaan DVA. Hal ini sesuai dengan Vital $^{28}$ yang mengemukakan bahwa pemeriksaan DVA dengan menggunakan pergerakan kepala aktif kurang sensitif untuk skrining fungsi VOR dibandingkan pergerakan kepala secara pasif.

Berdasarkan hasil penelitian ini disarankan untuk perlunya sejawat memberikan informed consent kepada pasien sebelum memberikan terapi streptomisin tentang risiko timbulnya gangguan keseimbangan dan pendengaran akibat streptomisin, sehingga pasien lebih waspada bila terjadi gangguan. DVAjuga dapat dilakukan sebagai skrining untuk mengetahui fungsi vestibuler perifer bilateral pada pasien yang mendapat terapi streptomisin. Jika DVA sudah digunakan sebagai skrining, maka pasien dengan pemeriksaan DVA positif dapat dilanjutkan pemeriksaan kalori bila fasilitas memungkinkan.

\section{DAFTAR PUSTAKA}

1. TB Case Notifications and Treatment Outcomes. 2013. In: Global Tuberculosis Report 2013 [Internet]. France: World Health Organization. [28-44].

2. Tuberculosis and Other Mycobacterial Infections. 2005. In: Harrison's Manual of Medicine [Internet]. United States of America: Mc Graw-Hill. 16th. [495-505].

3. Isbaniyah F, Thabrani Z, Soepandi PZ, Burhan E, Reviono, Soedarsono. Tuberkulosis. Pedoman Diagnosis dan Penatalaksanaan di Indonesia. Jakarta: Perhimpunan Dokter Paru Indonesia; 2011.

4. Pedoman Nasional Pengendalian Tuberkulosis. Jakarta: Kementerian Kesehatan Republik Indonesia Direktorat Jenderal Pengendalian Penyakit dan Penyehatan Lingkungan, 2011.

5. Stringer SP, Meyerhoff WL, Wright CG. Ototoxicity. In: Paparella MM, Shumrick DA, Gluckman JL, Meyerhoff WL, editors. Otolaryngology. Philadelphia: WB Saunders Company; 1991. p. 1653-69.

6. Schuman RM, Matz GJ. Ototoxicity. In: Bailey BJ, Jhonson JT, Newlands SD, editors. Head and Neck SurgeryOtolaryngology. 2. 4th ed. Philadelphia: Lippincot-William\&Wilkins 2006. p. 22015.

7. Kisilevsky VE, Tomlison RD, Ranali P, Prepageran N. Monitoring Vestibular Ototoxicity. 2004. In: Ototoxicity [Internet]. Ontario: BC Decker Inc; [161-9].

8. Petersan JA, Straumann D, P.Weber K. Clinical Diagnosis of Bilateral Vestibular Loss: Three Si,ple Bedside Tests. Ther Adv Neurol Disord. 2013;6(1):41-5.

9. Desmond AL. Function and Dysfunction of the Vestibular System. In: Liu S, editor. Vestibular Function: Evaluation and Treatment. New York: Thieme Medical Publisher; 2004. p. 21-43.

10. Domenick Vital M, Stefan C. A. Hegemann M, Dominik Straumann M, Oliver Bergamin M, Christopher J. Bockisch P, Dominik Angehrn DI, et al. A New Dynamic Visual Acuity Test to Asses Peripheral Vestibular Function. Arch Otolaryngol Head Neck Surg. 2010;136(7):689-91 
11. Desmond A. Screening Test for Vestibular Dsyfunction. In: Liu S, editor. Vestibular Function: Evaluation and Treatment. New York: Thieme 2004. p. 45-62.

12. Riset Kesehatan Dasar 2013. Jakarta: Badan Penelitian dan Pengembangan Kesehatan. Kementrian Kesehatan RI, 2013.

13. Indonesia PDP. Tuberkulosis: Pedoman Diagnosis dan Tatalaksabna. Jakarta. 2006.

14. Kim YH, Lee HL, Kim K-S, Choi H, Choi JS. Clinical Evaluation ad Early Diagnosis of Stteptomycin Ototoxicity. Int AdvOtol. 2011;7(1):91-5.

15. Ranger D. The Danger of Streptomycin With Particular Reference to The Vestibular Toxic Effects. Postgrad Med J. Jun 1959;35(404):344-6.

16. Timoteo MLL. Tuberculosis Treatment with Streptomycin : Auditory and Vestibular Profile. Rev Inst Med trop S Paulo. 2003;45(4):192.

17. Rizzi MD, Hirose K. Aminoglycoside Ototoxicity. Current Opinion in Otolaryngology Head and Neck Surgery. 2007; 15:352-7.

18. Singh H, GAudi S, Kher K. Vestibular Analysis in Streptomycin Ototoxicity. Indian Journal of Otolaryngology. 1981;33(2):63-6.

19. Kim YH, Lee HL, Kim K-S, Choi H, Choi JS. Clinical Evaluation ad Early Diagnosis of Stteptomycin Ototoxicity. Int AdvOtol. 2011;7(1):91-5.

20. Viljoen D, Sellars S, Beighton P. Familial Aggregation of Streptomycin Ototoxicity: Autosomal Dominant Inheritance? Journal of Medical Genetics. 1983;20:357-60.

21. Ahmed RM, Hannigan IP, MacDougall HG, Chan RC, Halmagyi GM. Gentamicin Ototoxicity: A 23-Year Selected Case Series of 103 Patients. MJA. 2012;196(11):701-4.
22. Goncalves DU, Felipe L, Lima TMA. Intepretation and Use of Caloric Testing. Rev Bras Otorrinolaringol. 2008;74(3):440-6.

23. Bernstein J, Burkard R. Test Order Effects of Computerized Dynamic Posturography and Calorics. American Journal of Audiology. 2009;18:34-44.

24. Zapala DA, Olsholt KF, Lundy LB. A Comparison of Water and Air Caloric Responses and Their Ability to Distinguish Between Patients with Normal and Impaired Ears. Ear \& Hearing. 2008;29(4):585-600.

25. Peters BT, Mulavarab AP, Cohenc HS, SangiHaghpeykarc H, Bloombergd JJ. Dynamic Visual Acuity Testing for Screening Patients with Vestibular Impairments. J Vestib Res. 2012;22(2):145-51.

26. Petersen JA, Straumann D, P.Weber K. Clinical Diagnosis of Bilateral Vestibular Loss: Three Simple Bedside Tests. Ther Adv Neurol Disord. 2013;6(1):41-5.

27. Zingler VC, Weintz E, Jahn K, Huppert D, Cnyrim C, Brandt T. Causative Factors, Epidemiology, and Follow-up of Bilateral Vestibulopathy. Ann N Y Acad Sci. 2009;1164:505-8.

28. Domenick Vital M, Stefan C. A. Hegemann M, Dominik Starumann M, Oliver Bergamin M, Christopher J. Bockisch P, Dominik Angehrn DI, et al. A New Dynamic Visual Acuity Test to Assess Peripheral Vestibular Function. Arch Otolaryngol Head Neck Surg. 2010;136(7):686-91.

29. Petersen JA, Straumann D, P.Weber K. Clinical Diagnosis of Bilateral Vestibular Loss: Three Simple Bedside Tests. Ther Adv Neurol Disord. 2013;6(1):41-5.

30. Schubert MC, Migliaccio AA, Santina CAD. Dynamic Visual Acuity During Passive Head Thrusts in Canal Plane. JARO. 2006;7:32938. 